\title{
A physician's descent into abject poverty for seeking help from a PHP
}

\author{
Anne Phelan-Adams \\ Consultative Medical Services, Blacksburg, VA, USA
}

Dr. Robert Wilkie should have been a happy man. He was exactly what he wanted to be in life, an emergency physician and hospitalist in a small, close-knit community. His work was a source of pride and pleasure, as were his religious community, his family and ice hockey, the sport he played growing up in Canada. Yes, Dr. Wilkie should have been a happy man, and for the most part, he was. Yet an undertow of melancholy always tugged at him. He usually kept his head above water, but sometimes the tug was so strong he feared he might drown, and this fear would set off a severe bout of anxiety and agitation.

Dr. Wilkie's father experienced many years of depression and Wilkie assumed that he had inherited from his father whatever snippet of DNA was responsible for that constant tug. Perhaps because it was a small town where everyone seemed to know everything about everyone or perhaps it was his fear that his board might find out about his psychological problems, Dr. Wilkie tried to keep his struggle to himself and did what the New Testament exhorted, Medice curate te ipsum - Physician, heal thyself which Wilkie took to mean Treat yourself. When his psychiatrist's treatment did not control his anxiety and agitation, he prescribed anti-anxiety medications to himself. Ultimately he became dependent on them to control his symptoms, although he never used them to excess. And

Correspondence: Anne Phelan-Adams, Consultative Medical Services, 1724 Sage Lane, 24060 Blacksburg, VA, USA.

E-mail: aphelanmd@gmail.com

Acknowledgments: I wish to thank P.J. Randhawa, investigative reporter with KSDK News 5 in St. Louis, Missouri for her efforts in exposing malfeasance by state medical boards and their Physician Health Services organizations.

Key words: Depression; anxiety; self-prescribing; physician health.

Received for publication: 31 October 2019.

Accepted for publication: 19 December 2019.

This work is licensed under a Creative Commons Attribution NonCommercial 4.0 License (CC BY-NC 4.0).

${ }^{\circ}$ Copyright: the Author(s), 2019

Licensee PAGEPress, Italy

Qualitative Research in Medicine \& Healthcare 2019; 3:136-138

doi:10.4081/qrmh.2019.8647 never did his anxiety and depression, or the medications he used to control them, affect his professional comportment or clinical acumen. And, as his profession demanded, on the surface, he was as calm and clear-eyed as a glass sea.

For many years, Dr. Wilkie was able to keep his struggles a private matter between himself and his personal psychiatrist. As investigative reporter P.J. Randhawa described in a televised interview with him in May 2019, ${ }^{1}$ "he was managing it pill by pill with anti-anxiety medications". In his 33 years of practice in Canada, Oklahoma and Missouri, never was there a complaint about his professionalism and never did he have a brush with the law more serious than a traffic violation. However, in 2008, while he was working at St. Francis Hospital, a patient lodged a complaint that he had stolen her prescription for a controlled substance. The hospital administration became concerned and ordered a drug test on him. The test was negative, but, because he could not provide unassailable proof to counter the patient's accusation, he was eyed with suspicion. At the hospital's urging, he sought an evaluation from his state Physician Health Program (PHP). PHPs are organizations affiliated with state medical boards that are intended to provide compassionate care to physicians struggling with mental health and substance abuse issues while keeping patients safe by monitoring their clinical performance.

As P.J. Randhawa ${ }^{1}$ stated, PHPs are supposed to help doctors with addiction or mental illness get well and return to practice. The problem is, once you ask your PHP for help, you're no longer in control. Your PHP decides where you go for your treatment. Rather than creating an individualized support and monitoring plan near his home that would allow him to maintain his ties with patients, family, friends and religious community, the PHP immediately pressured him to go to two board-affiliated out-ofstate evaluation and treatment centers. Because he did not meet the diagnostic criteria for inpatient or residential treatment, he had to pay for these services in cash. His confinement lasted five months and cost him his entire cash savings of $\$ 50,000$.

Dr. Wilkie said that these facilities did nothing for him. He would routinely see a psychiatrist who asked him the same thing each time, Hey Bob, how ya feeling? He would answer the same way each time, Terrible. The response 
was often, Sorry to hear that. But nothing more. No recommendation for changing his medications. No support groups. No ancillary treatment like biofeedback or meditation. Not even compassion for his predicament. Although he was in constant contact with others, never had he felt more isolated, powerless and insignificant than he did in those five months. Only his religious faith and determination to return to home and medical practice sustained him.

After a seemingly interminable confinement, Dr. Wilkie was finally given a clean bill of health to return to medical practice. While he was away, his position at St. Frances was filled by another hospitalist and, because of his now tarnished reputation, it took him months to find another position. He finally found work covering the practice of a colleague who was recuperating from a serious illness. He was thrilled to be practicing again but the thrill was short-lived. During his absence from work, Wilkie's Bureau of Narcotics and Dangerous Drugs (BNDD) license had expired. In Missouri and many other states, a BNDD or similar license is required for a physician to prescribe scheduled (potentially habit-forming or addictive) medications like narcotics. Unaware of the lapse, he continued to refill prescriptions for scheduled medications that his colleague's patients were already taking. When the BNDD and medical board discovered the lapse, he was arrested, taken to jail and charged with a felony. His picture and the charges against him made the front page of the local newspaper which made him feel deeply ashamed. The charges were eventually pleaded down to a misdemeanor but, rather than revoking only his privilege to prescribe controlled substances and assigning another physician to supervise him, the Board suspended his medical license altogether.

At the same time, using the threat of permanently revoking his license, the board pressured him to sign a three-year treatment and monitoring contract that was later extended to five years after he had a brief relapse with sedative use. He described the contract as a full-time job in itself, one that he had to pay for out-of-pocket even though he no longer had an income. He had to see both a psychiatrist and a substance abuse specialist once a month, take random urine drug tests several times per month and attend support meetings three times a week. He also had to comply with all the requirements for keeping his medical license in otherwise good standing, including membership in the Missouri Medical Association and participation in continuing medical education and recertification exams. These requirements cost him about $\$ 1200$ per month.

Dr. Wilkie recalled that all the substance abuse specialist did was talk about Tiger Woods and all the psychiatrist did was keep scheduling return visits. I was just easy money, he remarked with some bitterness. His treating physicians were driving expensive new vehicles while he had only a beater car that kept getting more beaten up with the passage of time. His world shrank as he gave up, one after another, simple pleasures like visiting family in Canada, dining out, and enjoying fellowship with fellow parishioners. His wife had to work up to sixty hours a week just to keep the lights on; their marriage was buckling under the strain. The undertow of loss and sorrow and self-deprecation became so strong that Wilkie feared he would drown in his grief. Every day he prayed to God for the strength to persist but he was becoming exhausted from the effort.

As time passed, Dr. Wilkie's financial situation became increasingly dire. Eventually, no longer able to pay for gas and automobile insurance, he sold his car and rode a bus to his appointments. Hemorrhaging money month after month trying to comply with his PHP's demands, he eventually funneled all the equity in his home and retirement account into his ongoing expenses. In 2014, the well ran dry. Wilkie had worked for more than thirty years in a profession that should have allowed him to live comfortably into old age. But now, six years after asking his PHP for help, he was destitute. Living in a recreational vehicle that lacked indoor plumbing, he and his wife were forced to use a chemical latrine in their backyard and shower at a local community center. By that time, he had no internet, no income other than Canadian social security and no means to pay for his tests and appointments. But he still had a year left on his contract with PHP before his license could be reinstated; he was drowning in an ocean of impossible demands.

In a final effort to restore his license and livelihood, early in 2015, Dr. Wilkie requested a hearing with the Board to appeal his license suspension. He worked for days on a dossier that included his resume, explanations and apologies for his mistakes, and statements from his current physicians asserting that he was fit to practice medicine. On the day of his hearing, Wilke managed to summon up the courage to enter the courtroom even though he could not afford an attorney. He handed his dossier to the chairman of the Board of Medicine who also was the judge. Facing the chairman and the rest of the board, who served as the jury, as well as the board's seasoned lawyer, he pleaded his case. He told the board that he had done his best to comply with its orders but, because his license was suspended, he could not generate any income and was now destitute. Could the board forgive the final year of his contract? Could they set up a fund for impoverished doctors like him to pay for their tests and appointments? Could they somehow find it in their hearts to forgive his past mistakes and give him another chance? $\mathrm{He}$ added that, as a trained and experienced practitioner in acupuncture, as well as deep relaxation and inner healing techniques, he could be of great benefit to patients with just an active medical license. He would not need a BNDD license.

The Board chair skimmed through Wilkie's dossier, but none of the jury members looked at it. They did not 
take long to make up their minds to suspend his license with no pathway for redemption.

Dr. Wilkie had indeed made mistakes. Nothing immoral, nothing criminal, and nothing that put patients in harm's way, but he did make mistakes. His BNDD registration lapsed during his confinement and he continued to prescribe narcotics to his colleague's patients for another two months. He had intermittently treated himself with anti-anxiety medications when his agitation became more than he could bear. But his biggest mistake was trusting his PHP to help him. Had he been forewarned about the system's malevolence, had he gotten a lawyer early on and had he avoided the PHP, his career might not have been washed out to sea like a pile of wayward driftwood.

Intrigued by Dr. Wilkie's televised interview in 2019, I arranged to speak with him over the phone. I listened intently as he quietly described his devotion to the practice of medicine, to his family and to God. About growing up in Canada and his lifelong love of ice hockey. The years' long fight with mental illness. The toll the PHP's mandates took on his marriage. His struggle with suicidal thoughts as his life circled the drain after his license was suspended. His religious faith that kept him from taking his own life.

Long after his license was suspended, Wilkie finally found a psychiatrist who diagnosed him with bipolar illness and attention deficit disorder. With the right medications, he had more energy and optimism than he had had in years and no longer suffered from the bouts of anxiety and agitation that, in the past, compelled him to use prescription sedatives. If only he could put his renewed vigor into patient care, he mused, he would truly be a happy man.

Towards the end of our interview, I asked Dr. Wilkie if he wanted me to communicate anything specific to his colleagues. In spite of the embarrassment and criticism he might face, he asked me to warn his colleagues about this punitive process that had done nothing but drive him into poverty and despair. If I'd only known...I have nothing to lose now. So, yes, tell them who I am; tell them what happened to me; tell them what could happen to them. And please tell them to get a lawyer. Physicians shouldn't lose their careers simply because they've run out of money, he added emphatically.

Dr. Wilkie was not alone in his plight. In the three years since I've been researching the issue, I've come across dozens of physicians and other health care providers who have been similarly mistreated and misdiagnosed by their PHPs and medical boards. Physicians with only minor or past substance use problems who are diagnosed with addiction. Physicians who merely had a drink or two after work who are diagnosed with alcoholism. Physicians with mental health problems who were diagnosed with substance abuse instead. In almost every case, these physicians were remanded to ninety days of confinement in a drug rehab facility followed by three to five years of expensive and unnecessary treatment just to continue practicing medicine. Regardless of the outcome, the process always left emotional, financial and reputational scars.

Yet there was something special about this man. $\mathrm{He}$ lost almost everything: his home, his medical license, his retirement funds. But there was one thing he did not lose. Dr. Robert Wilkie was a man of God and he never lost his faith.

\section{References}

1. Randhawa PJ. Doctor left destitute after seeking help from a PHP. KSDK 5 on your side. Televised 21 May 2019. Available from: https://www.youtube.com/watch?v=O9DbEgAZgyM 